\title{
Novos desafios: A Biologia da Crença
}

New Challenges: The Biology of Belief

Nuevos desafíos: La biología de la creencia

Isis Suruagy Correia Moura $^{1}$

A ciência vem se libertando de velhos mitos, criando novas crenças relacionadas à civilização segundo $\mathrm{o}$ autor do livro A Biologia da Crença, Bruce H Lipton. Cientista e docente de Universidades norte americanas, conhecido por discutir a Epigenética que estuda os mecanismos moleculares pelos quais o meio ambiente controla a atividade genética, sendo uma das áreas mais atuante da pesquisa cientifica em geral.

A Epigenética aborda as modificações do genoma que são herdadas pelas próximas gerações, mas que não alteram a sequência do DNA.
Por muito tempo acreditou-se que os genes eram os únicos responsáveis por passar as características biológicas de uma geração à outra, todavia isso vem se modificando nos últimos tempos e hoje cientistas compreendem que variações não-genéticas (epigenéticas) adquiridas durante a vida de um organismo podem ser repassadas aos seus descendentes. Lipton também acredita que os que genes e DNA podem ser manipulados pelas crenças de uma pessoa.

O livro apresentado em oito capítulos é redigido em uma linguagem accessível a leigos e aos mais experientes da área da biologia, promovendo uma

${ }^{1}$ Graduada em Nutrição pela (UFAL). Graduada em Educação Física pela Estácio (FAL). Mestre em Nutrição pela (UFAL). Doutora em Neuropsiquiatria e Ciência do Comportamento pela (UFPE). Autora correspondente: Av. Emp. Carlos da S. Nogueira. 16, apto 303, Jatiúca, Maceió, AL, Brasil. CEP: 57036540. E-mail: isis_suruagy@yahooo.com.br Recebido: Dez/2016 - Aceito: Jan/2017. 
leitura agradável e atraente, permeando vivências pessoais do pesquisador e suas descobertas teóricas.

Assim, no primeiro capítulo o autor relata a inteligência das células e dos alunos de uma faculdade de Medicina o Caribe, nos anos seguintes a uma crise existencial que o fez deixar seu posto de Professor Adjunto da Escola de Medicina, Universidade de Wisconsin, descobrindo no Caribe a parceria e a harmonia entre os elementos da natureza, isso $\mathrm{o}$ fez refletir sobre os conceitos tradicionais da biologia sobre a luta pela sobrevivência, descobrindo que a mente consciente está muito além da mera programação genética. A inteligência das células, para o autor tem a capacidade de ensinar sobre a nossa mente e de nosso corpo. As células são seres humanos em miniatura.

No segundo capítulo, encontra-se as evidências científicas que desvendam como a natureza (meio ambiente) pode influenciar o comportamento das células sem modificar o código genético. Expõe que o ambiente é responsável pela manifestação ou não do gene e que este não se manifesta por si só, quando se trata de controle genético o que fala mais alto é o ambiente, expondo também que ao se estabelecer um ambiente saudável para a cultura de células elas se tornam mais resistentes.
O capitulo 3 trata sobre a membrana das células, fazendo uma analogia desta com a pele do corpo humano. Ele expõe que a membrana é o cérebro da célula, ideia pessoal de anos atrás que vem sendo confirmada pela ciência atual.

Max Planck pesquisando a energia irradiada pelo espectro da radiação térmica, expressa como ondas eletromagnéticas produzidas por organismo emissor de calor chegou a constante de Planck, que modificou os princípios da física clássica, iniciando a trajetória da Física ou Mecânica Quântica. Einstein foi o primeiro a utilizar o termo quantum para a constante de Planck em uma publicação em 1905, quando estudava as consequências dos fenômenos fotoelétricos e desenvolveu o conceito de fóton. $\mathrm{O}$ fóton está relacionado a um evento físico chamado de quantização, que é quando um elétron passa de uma energia mínima para o nível posterior, se for aquecido, isto sem passar por estágios intermediários, realizando assim um salto energético de um valor para outro.

Os resultados disto são manifestos macroscopicamente e essa teoria vem revolucionando as ideias tanto no âmbito das Ciências Exatas como nas discussões filosóficas vigentes. O capitulo 4 , sobre essa nova física e como plantar 
firmemente os pés no ar, versa sobre as descobertas da física quântica e seu impacto sobre a compreensão e tratamento das doenças, expondo que a medicina tradicional ainda não incorporou de todo seus conceitos às suas pesquisas e à formação acadêmica do médico.

O capitulo 5 discute crenças e pensamentos humanos que influenciam o comportamento, controlando assim, a vida humana. Para Lipton, a realidade de um universo quântico retoma conceitos que Descartes refutou explicando que a nova concepção da mecânica do universo mostra que o corpo físico pode ser afetado pela mente não material. Descartes negou a influência da mente sobre o corpo, o que é discutido em outro livro sobre o erro de Descartes, de Damásio. Desta forma começa-se a questionar a biomedicina tradicional que é baseada em um universo puramente físico e nos conceitos de Newton, em concordância com Descartes, levando a uma nova reflexão sobre os termos médicos. Surge a concepção de que o corpo físico pode ser afetado pela mente não material.

O capítulo 6 versa sobre o medo que limita o crescimento de pessoas e células, relatando que a evolução tem mecanismos divididos a grosso modo em crescimento e proteção. Informa que o medo mata, e que as células necessitam passar por processos de crescimento e proteção.

No capítulo 7 surge a importância da paternidade consciente e como pais precisam entender o seu papel na a programação das crenças dos filhos e do impacto dessas crenças em suas vidas. $\mathrm{O}$ inconsciente tem poder que ainda são desconhecidos pela humanidade que não está familiarizada com seu estudo, ao longo da evolução adquirimos percepções que se fortificam. Mecanismos fisiológicos do corpo como batimentos cardíacos, fluxo sanguíneo e temperatura corporal são instintos programados naturalmente. Todavia os iogues aprenderam regular conscientemente essas funções.

Finalmente o epílogo traz a percepção do autor da importância da integração espirito-ciência e como ele foi modificado em sua visão agnóstica e científica que possuía a respeito do mundo.

\section{Referência}

1. Lipton BH. A Biologia da Crença: o poder da consciência sobre a matéria es milagres. São Paulo: Butterfly; 2017. 